\title{
Calcium Carbonate and Temperature as Tools for Manipulation of Coastal Sediment Acidification: A Laboratory Study
}

\author{
Brian Matthew Prezoisi ${ }^{1, ~ *, ~ T i m o t h y ~ J a m e s ~ B o w d e n ~}{ }^{1}$, Aria Amirbahman ${ }^{2}$ \\ ${ }^{1}$ School of Food and Agriculture, University of Maine, Orono, the United States \\ ${ }^{2}$ Department of Civil and Environmental Engineering, University of Maine, Orono, the United States
}

Email address:

brian.preziosi@maine.edu (B. M. Preziosi)

${ }^{*}$ Corresponding author

\section{To cite this article:}

Brian Matthew Prezoisi, Timothy James Bowden, Aria Amirbahman. Calcium Carbonate and Temperature as Tools for Manipulation of Coastal Sediment Acidification: A Laboratory Study. International Journal of Environmental Monitoring and Analysis.

Vol. 7, No. 6, 2019, pp. 118-127. doi: 10.11648/j.ijema.20190706.12

Received: October 20, 2019; Accepted: November 11, 2019; Published: December 2, 2019

\begin{abstract}
The spread of low-pH sediments (also known as dead muds) has brought about the need for laboratory studies involving acidified sediment. $\mathrm{CO}_{2}$ bubbling is traditionally used to acidify the sediment; however, allowing the native sediment bacteria to do the acidification is a more natural approach. The objective of the current study was to test if the surface sediment could be acidified using the sediment bacteria and determine how long the sediment chemistry stayed stable for. The $\mathrm{pH}$ of sediment taken from near Dobbins Island in Beals, ME, was monitored in sediment containers distributed evenly among 20 -gallon aquaria containing artificial seawater for 74 days. Half of these aquaria were kept at $6.5^{\circ} \mathrm{C}$ while the other half were kept at $24^{\circ} \mathrm{C}$. Each sediment bed had a depth of $15 \mathrm{~cm}$ and had pore water samples taken via syringe at the top, middle and bottom of the sediment column every 2-3 days. Crushed razor clam (Ensis leei) shell was applied to half of these sediment beds on day 33 . The results show surface sediment pore water chemistry can be kept at acidified conditions $\left(\sim 6.0 \mathrm{pH} / \sim 500 \mu \mathrm{mol} \mathrm{kg}^{-1}\right.$ total alkalinity/ less than 0.04 aragonite saturation state) or ambient collection site conditions $\left(\sim 6.8 \mathrm{pH} / \sim 4000 \mu \mathrm{mol} \mathrm{kg}^{-1}\right.$ total alkalinity/ 0.10-0.25 aragonite saturation state) for month-long periods by incubating the sediment in recirculating aquaria or applying crushed E. leei shell respectively. Higher temperatures reduce the incubation time needed to acidify the sediment but shorten the period the surface sediment remains at $6.0 \mathrm{pH}$ for. Before using the method, researchers should run a preliminary experiment with a batch of the sediment they intend to use to insure the sediment acidification intensity and duration meets their needs.
\end{abstract}

Keywords: Sediment Acidification, Laboratory Method, pH, Aragonite Saturation State

\section{Introduction}

Sediment acidification is caused by rapid decay of organic matter and often leads to decreases in sediment pore water $\mathrm{pH}$, alkalinity, and carbonate saturation state. Most of the acidification occurs at the sediment surface because oxygen is required for rapid organic matter decomposition, which is generally only available in the top few centimeters $[1,2]$. In coastal environments, there is an abundance of organic matter falling from the water column above to fuel this process. Organic matter, however, is not evenly distributed on the sediment surface. Large concentrations of organic matter can be deposited on the sediment surface through die-offs of algal blooms. The rapid growth of the algae is fueled by nitrogen pollution from land, a process known as eutrophication [3]. The organic matter on the sediment can then be relocated through the burrowing action of benthic macro fauna, which also affects sediment exposure to oxygen [2]. As a result, the sediment surface $\mathrm{pH}$ can vary significantly from 6.0 to 8.2 across different sites and times of the year [2, 4]. Values on the lower end of this range have been observed at individual sites in both the Bay of Fundy and the coast of Maine [4-6].

Sediment acidification also often leads to the reduction of carbonate saturation state $(\Omega)$. Calcium carbonate $\left(\mathrm{CaCO}_{3}\right)$ is 
formed and dissolved according to the following equation:

$$
\mathrm{CaCO}_{3} \leftrightarrow \mathrm{Ca}^{2+}+\mathrm{CO}_{3}^{-2}
$$

where $\mathrm{Ca}^{2+}$ is the concentration of calcium ions and $\mathrm{CO}_{3}{ }^{-2}$ is the concentration of carbonate ions. As $\mathrm{pH}$ decreases, excess hydrogen ions $\left(\mathrm{H}^{+}\right)$bind to carbonate ions to form bicarbonate ions $\left(\mathrm{HCO}_{3}^{-}\right)$and thus decrease the concentration of carbonate ions available. This can reduce the $\Omega$, which can be calculated using the following equation:

$$
\Omega=\left[\mathrm{CO}_{3}^{2-}\right]\left[\mathrm{Ca}^{2+}\right] / \mathrm{K}_{\mathrm{sp}}
$$

where $\mathrm{K}_{\mathrm{sp}}$ is the stoichiometric solubility product, dependent of the carbonate mineral phase (aragonite, calcite, low $\mathrm{Mg}$ calcite, high Mg calcite), temperature, salinity, and pressure. Calcium ions are readily available in most marine environments so the concentration of carbonate ions usually drives the $\Omega$ [7]. Precipitation of the calcium carbonate $\left(\mathrm{CaCO}_{3}\right)$ shells invertebrates need to survive is thermodynamically favored when $\Omega>1$ while dissolution is thermodynamically favored when $\Omega<1$ [8]. Invertebrates are still capable of producing calcium carbonate when $\Omega<1$, however they must pay a higher metabolic cost to do so [9$11]$.

Sediment acidification has already been identified as a major environmental stressor for a variety of clam species, including, the soft shell clam Mya arenaria, the hard shell clam Mercenaria mercenaria, and the Manilla clam Ruditapes philippinarum [6, 7, 12-14]. Young clams are particularly vulnerable to this stressor. M. arenaria in the $\sim 0.2 \mathrm{~mm}$ size class begin to suffer increased mortality rates at sediment $\mathrm{pH}<$ 7.3. Clams become more resilient to the stressor as they grow larger $(\sim 0.4 \mathrm{~mm}$ M. arenaria survival is not impacted until $\mathrm{pH}$ 7.0 ; [6], but even $R$. philippinarum adults have $100 \%$ mortality after being exposed to $\mathrm{pH} 6.1$ sediments for ten days [14]. The need to cope with acidic sediments becomes especially important for razor clams, such as the Atlantic Jackknife clam Ensis leei. This species must spend the majority of its life at the surface of the sediment due to its short siphons, and has no way to seal its soft tissues off from the external environment [15]. It is essential to protect these clam species as they are have ecologic and economic value [15, $16]$.

Laboratory studies can be used to assess how much acidification each species of clam can tolerate; these results would be valuable to the growers. Techniques for manipulating and monitoring seawater chemistry by changing the carbonate concentration in the laboratory setting are well defined at this point [17, 18]. The techniques for the manipulation of marine sediment chemistry by changing carbonate concentration, however, are still in development. Furthermore, research on the impacts of sediment acidification on infaunal marine bivalves is in short supply [16]. The majority of laboratory studies conducted involving sediment acidification impacts on clams make use of quick bursts of $\mathrm{CO}_{2}$ gas to acidify the sediment while air from an aquarium pump is bubbled in a control group. This method produces a stable sediment $\mathrm{pH}$. However, it does not mimic the natural acidification process, which is driven by the aerobic decay of organic matter [16].

Adding crushed bivalve shells has been shown to increase sediment $\mathrm{pH}$, and thus, might serve as a natural method of restricting the sediment $\mathrm{pH}$ in the laboratory to collection site values. An increase of $\sim 0.3 \mathrm{pH}$ units was achieved using $M$. arenaria shells crushed down to a $1 \mathrm{~mm}$ grain size during a 30 day field study [19]. Field sediments have also been successfully buffered using a mix of $70 \%$ Crassostrea gigas shells and $30 \%$ mixed-species clam shells crushed to a grain size of $5 \mathrm{~cm}$ or less. Sediments treated with this mixture were $\sim 0.2 \mathrm{pH}$ units higher than untreated sediments after 55 days [20]. The controlled conditions of laboratory aquaria should allow for these field methods to be modified so that the crushed shell counteracts the acidification caused by the sediment bacteria without raising the $\mathrm{pH}$ higher than collection site values.

The current work aims to show coastal sediment can be acidified in the laboratory using the natural metabolic processes of sediment bacteria. Spreading crushed E. leei shell is proposed as a method to counteract acidification and keep the sediment chemistry close to collection site parameters in the control group. Acidifying sediment in the laboratory using the decay of the pre-existing organic matter would allow the creation of mesocosms that more closely mimic the natural environment. The primary concern with this method, however, is the pH stability that is largely dependent on the metabolic processes of the sediment bacteria with respect to the production of carbonate species [2]. The sediment chemistry of coastal sediment kept in recirculating aquaria will be monitored over 74 days at $24^{\circ} \mathrm{C}$ and $6.5^{\circ} \mathrm{C}$ to determine if the sediment acidifies at either of these temperatures and assess the stability of the solution chemistry once acidification has stopped. The reported solution chemistry parameters will include sediment $\mathrm{pH}$, total alkalinity, and aragonite saturation state $\left(\Omega_{\mathrm{ar}}\right)$, because aragonite is the calcium carbonate mineral phase found in most clam shells $[21,22]$. Successful manipulation of sediment chemistry allows for testing the acidification tolerance of clams as well as other burrowing invertebrate species in the laboratory.

\section{Materials and Methods}

\subsection{Sediment and Shell Collection}

Sediment was collected from a site near Dobbins Island in

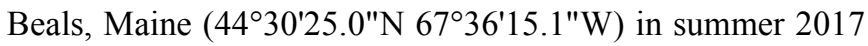
from a 10 square meter surface area in the lowest portion of the intertidal zone. This area was only exposed during negative tides and well populated with $E$. leei. The $\mathrm{pH}$ values of the overlying water, as well as the sediment at $0-3 \mathrm{~cm}$ (surface sediment), 4-7 cm, and 12-15 cm depth were recorded from $10 \mathrm{~mL}$ water samples taken via a $20 \mathrm{~mL}$ syringe $(\mathrm{n}=3$ for each depth) and analyzed with an Accumet portable $\mathrm{pH}$ meter (model AP115) equipped with an Accumet pH/ATC probe. The sphere of influence for a $10 \mathrm{~mL}$ draw in the 
sediment was determined to be $3 \mathrm{~cm}$ or less based on another study that used the syringe method [23]. Pore water samples were then gently poured into individual tubes, each containing $10 \mu \mathrm{L}$ of saturated mercuric chloride solution to preserve the sample until it could be analyzed for total alkalinity. The tubes were then inverted five times to insure the mercuric chloride spread throughout the sample. Overlying water temperature and salinity were also recorded using the $\mathrm{pH}$ probe and an ATC portable refractometer $(\mathrm{n}=3$ for each). The top $\sim 20 \mathrm{~cm}$ of sediment $(\sim 18 \mathrm{~L})$ was collected using a shovel and transferred to the laboratory in 5 gallon buckets. Sediment cores were also taken from the collection site by pushing $50 \mathrm{ml}$ polypropylene centrifuge tubes straight down into the sediment to a depth of $\sim 6 \mathrm{~cm}$. These cores, in addition to three samples of sieved $(2.54$ $\mathrm{mm}$ mesh) sediment from the top $\sim 20 \mathrm{~cm}$, were analyzed later for water content, grain size distribution, and percent organic matter (see section below for full methods). All pebbles and large invertebrates were removed from the shoveled sediment using a sieve with $2.54 \mathrm{~mm}$ mesh size within $10 \mathrm{hr}$ of sediment collection. E. leei shells were also collected at the Dobbins Island site. The shells were later rinsed with distilled water and heated $\left(\sim 100{ }^{\circ} \mathrm{C}\right.$ for $\left.2 \mathrm{hr}\right)$ before they were ground up to a grain size of $<3 \mathrm{~mm}$ using a mortar and pestle. E. leei shells were chosen because they are made primarily of aragonite, which dissolves faster than other forms of calcium carbonate [22, 24].

\subsection{Water Content, Grain Size, and Percent Organic Matter}

Percent organic matter and grain size distribution was determined for both cores that went down to a sediment depth of $6 \mathrm{~cm}(\mathrm{n}=2)$ and sieved $(2.54 \mathrm{~mm}$ mesh) sediment from the top $\sim 20 \mathrm{~cm}(\mathrm{n}=3)$. Organic matter analysis on cores was done for the $0-2,2-4$, and 4-6 cm sections of each core. Grain size analysis was carried out on the sediment from the entirety of the 2 cores combined as well as each of the 3 samples $(\sim 100 \mathrm{~g}$ each) from the sediment collected by shovel from the top $\sim 20$ $\mathrm{cm}$ of the sediment. All sediment was dried at $120^{\circ} \mathrm{C}$ for 24 hours to both determine water content and prepare it for analysis. Percent water content was determined by dividing the mass of the dried sediment by the wet sediment, multiplying it by 100 , and then subtracting it from 100 . Grain size analysis was carried out by putting dried sediment through a series of sieves stacked on top of each other with a pan at the bottom to catch grains small enough to go through all sieves [25]. The sieve numbers and mesh sizes used going from the top to the bottom of the stack were \#20 $(840 \mu \mathrm{m})$, \#40 $(425 \mu \mathrm{m}), \# 60(250 \mu \mathrm{m}), \# 20(75 \mu \mathrm{m})$. The mass of the sediment remaining on each sieve was divided by the initial mass of the dry sample before being sieved and multiplied by 100 to determine the percent composition for each grain size range. The sediment was then characterized according to 4 grain size categories: gravel or very coarse sand (greater than $840 \mu \mathrm{m})$, coarse to medium sand $(840-425 \mu \mathrm{m})$, fine to very fine sand (425-75 $\mu \mathrm{m})$, and silt or mud (less than $75 \mu \mathrm{m})$ [26]. Percent organic matter was determined using the loss on ignition method. The weight of the sediment after combustion at $550^{\circ} \mathrm{C}$ was subtracted from the initial dry weight of the sediment. This was then divided by the initial dry weight and multiplied by 100 to obtain the percent organic matter [27].

\subsection{Experiment Setup}

The sediment was distributed among 12 rectangular polystyrene containers measuring $18 \times 12.5 \times 12.5 \mathrm{~cm}$ (height, length and width). Each container (henceforth referred to as sediment beds) was filled up to the $15 \mathrm{~cm}$ depth with sieved sediment and placed within $6 \times 75 \mathrm{~L}$ aquariums $(2$ beds per aquarium) filled with $30 \mathrm{ppt}$ artificial seawater made with Tropic Marin Pro Reef mix for 74 days. Three aquaria were kept at $24 \pm 0.04^{\circ} \mathrm{C}$ ( \pm standard error of the mean) using aquarium heaters, while the other three were kept at $6.5 \pm$ $0.03^{\circ} \mathrm{C}$ using chillers. All aquaria were constantly aerated although one of the air pumps used for a $24^{\circ} \mathrm{C}$ aquarium failed during the experiment (this aquarium was removed from the data set). On day 33, one sediment bed was taken out from each aquarium to have $150 \mathrm{~g}$ of crushed E. leei shell $(1.4 \mathrm{~g}$ $\mathrm{cm}^{-2}$ ) added to its sediment surface. The crushed shell was then lightly pressed into the top $1 \mathrm{~cm}$ of sediment by hand before the sediment beds were slowly placed back into respective aquaria. All aquaria were covered with black polythene for the first 10 days of the experiment to reduce the light levels during the initial acidification of the sediment and thus limit any potential photosynthetic activity from diatoms present on the sediment surface.

\subsection{System Monitoring and Data Analysis}

Monitoring of the $\mathrm{pH}$ and total alkalinity of these 4 different groups of sediment beds over a 74 day period allowed for observation of both short and long term trends of sediment chemistry. Pore water samples were taken via syringe at the top of the sediment column $(0-3 \mathrm{~cm})$ at every 2-3 days, and from the middle $(4-7 \mathrm{~cm})$ and bottom $(12-15$ $\mathrm{cm})$ depths at every 10-12 days. The $\mathrm{pH}$ of a $10 \mathrm{~mL}$ pore water sample (extracted via syringe) was measured immediately after being expelled into a $15 \mathrm{~mL}$ tube which was then poisoned with $10 \mu \mathrm{L}$ of saturated mercuric chloride to preserve the sample until it could be analyzed for total alkalinity. The titrations for total alkalinity were done using the open cell titration method [17], but was modified for smaller sample volumes. A $5 \mathrm{~mL}$ sample was placed into a 15 $\mathrm{mL}$ tube and titrated with $0.01 \mathrm{~N} \mathrm{HCl}$ prepared using a $30 \mathrm{ppt}$ $\mathrm{NaCl}$ solution down to a $\mathrm{pH}$ of 3.00. The $\mathrm{pH}$ and temperature were recorded. Mixing between acid additions was achieved by moving the probe up and down. The $\Omega_{\mathrm{ar}}$ was calculated from total alkalinity, $\mathrm{pH}$, and salinity values using CO2SYS (ver. $2.1 \mathrm{http}: / /$ cdiac.ess-dive.lbl.gov/ftp/co2sys/) and the $K_{1}$ and $K_{2}$ values recommended for estuarine waters [28]. The $\mathrm{pH}$, total alkalinity, and $\Omega_{\mathrm{ar}}$ of the 3 measured depths and overlying water were then compared to each other using one-way ANOVA and Tukey's multiple comparisons tests. Linear regression analysis was used to determine if significant changes in $\mathrm{pH}$, alkalinity, or $\Omega_{\mathrm{ar}}$ occurred in any of the treatments being kept in the aquaria by testing if the line of best fit had a slope significantly different from zero. Repeated measures one-way ANOVA followed by Tukey's 
multiple comparisons was used instead of linear regression for the 4-7 and 12-15 cm depths of the treatments with crushed shell since only 3 data points were acquired for these depths. All data analyzed met normality and equal variance assumptions. GraphPad Prism (ver.8.0.1 https://www.graphpad.com/scientific-software/prism/) was used to generate figures and perform statistical tests (all at the 0.05 significance level).

\section{Results}

\subsection{Collection Site Chemistry and Composition}

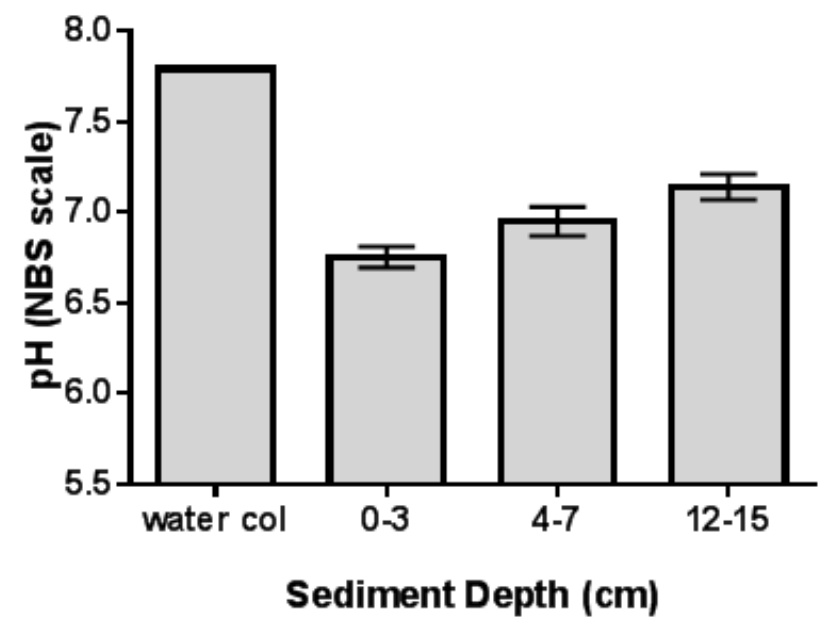

Figure 1. Sediment and overlying water pH near Dobbins Island. Each bar represents an average. The "water col" label indicates $\mathrm{pH}$ of the overlying water. $n=3$ per bar. Error bars $=$ standard error of the mean.

The $\mathrm{pH}$ of the collection site sediment was lowest at the surface and increased with depth. The average $\mathrm{pH}$ of the surface sediment $(6.75 \pm 0.06)$ was significantly lower than the sediment at the $12-15 \mathrm{~cm}$ depth $(7.14 \pm 0.07)$ (Tukey's multiple comparison test, $\mathrm{p}=0.009)$, but none of the other depths were significantly different from each other (Tukey's multiple comparison test, $\mathrm{p} \geq 0.183)$. The $\mathrm{pH}$ of the waters overlying the sediments $(7.79 \pm 0.01)$ was significantly higher than at any of the measured sediment depths (Tukey's multiple comparison test, $\mathrm{p}<0.001$ for all comparisons), which were $6.75 \pm 0.06(0-3 \mathrm{~cm}), 6.95 \pm 0.08(4-7 \mathrm{~cm})$, and $7.14 \pm 0.07$ $(12-15 \mathrm{~cm})$ (Figure 1). There were no significant differences in total alkalinity between the overlying water $(1947 \pm 18$ $\left.\mu \mathrm{mol} \mathrm{kg}{ }^{-1}\right)$ and any of the sediment depths, which were $3760 \pm$ $540 \mu \mathrm{mol} \mathrm{kg}{ }^{-1}(0-3 \mathrm{~cm}), 3843 \pm 328 \mu \mathrm{mol} \mathrm{kg}{ }^{-1}(4-7 \mathrm{~cm})$, and $4187 \pm 1426 \mu \mathrm{mol} \mathrm{kg}{ }^{-1}(12-15 \mathrm{~cm})$ (Tukey's multiple comparison test, $\mathrm{p} \geq 0.254)$. There were also no significant differences in total alkalinity among any of those sediment depths (Tukey's multiple comparison test, $\mathrm{p} \geq 0.979$ ). The $\Omega_{\mathrm{ar}}$ followed the same trends as the $\mathrm{pH}$. The overlying waters were saturated with respect to aragonite (just over 1.0) and all the measured sediment depths were undersaturated with respect to aragonite with averages ranging from $\sim 0.1$ to $\sim 0.7$. Both the sediment surface $(0.22 \pm 0.05)$ and $4-7 \mathrm{~cm}$ depth $(0.30$ \pm 0.04 ) had an average $\Omega_{\text {ar }}$ significantly lower than that of the overlying water $(1.05 \pm 0.03)$ (Tukey's multiple comparison test, $\mathrm{p} \leq 0.005)$. The surface sediment had a lower average $\Omega_{\mathrm{ar}}$ $(0.22 \pm 0.05)$ than the $4-7 \mathrm{~cm}(0.30 \pm 0.04)$ and $12-15 \mathrm{~cm}$ depths $(0.67 \pm 0.2)$ did, but there were no significant differences between any of these sediment depths (Tukey's multiple comparison test, $\mathrm{p} \geq 0.066$ ) (Figure 2). The average salinity and temperature of the overlying water was $30 \mathrm{ppt}$ and $19.1^{\circ} \mathrm{C}$ respectively.

The $6 \mathrm{~cm}$ sediment cores from the site had a water content of $31 \%$. Sediment cores were comprised of $17.3 \%$ gravel or very course sand, $5.0 \%$ coarse to medium sand, $76.0 \%$ fine to very fine sand, and $1.7 \%$ silt or mud. The sieved sediment from the top $\sim 20 \mathrm{~cm}$ had a water content of $30.4 \%$. This sediment was comprised of $9.5 \%$ gravel or very coarse sand, $4.1 \%$ coarse to medium sand, $84.6 \%$ fine to very fine sand, and $1.8 \%$ of silt or clay. The organic matter of all the sediment was between 4.0 and $4.3 \%$.

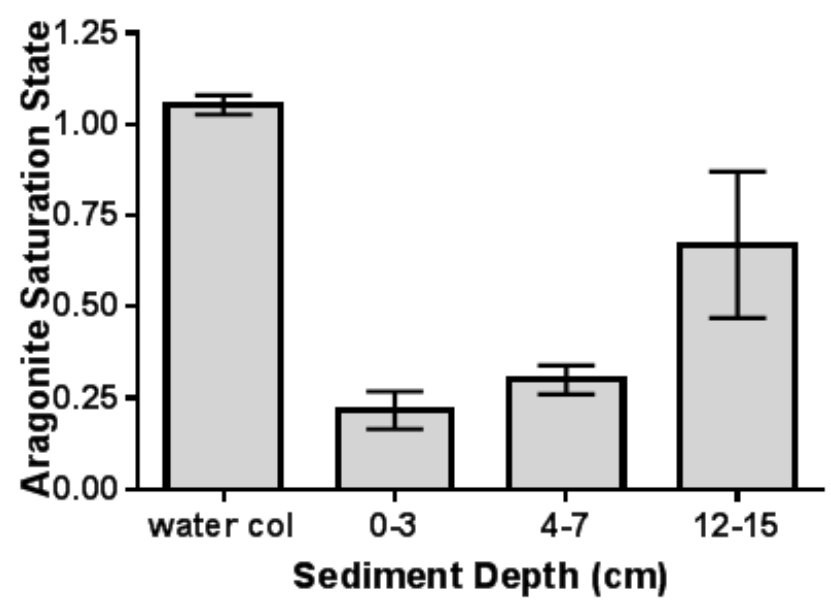

Figure 2. Sediment and overlying water aragonite saturation state near Dobbins Island. Each bar represents an average. The "water col" label indicates $p H$ of the overlying water. $n=3$ per bar. Error bars $=$ standard error of the mean.

\subsection{Solution Chemistry of Aquarium Water}

The $\mathrm{pH}$ of the overlying water in all aquaria remained between 7.83 and 8.11 for the duration of the experiment (Figure 3a), although the gradual increase from the low to high end of this range was significant at $24^{\circ} \mathrm{C}$ (linear regression for $24^{\circ} \mathrm{C}, \mathrm{p}<0.001$; linear regression for $6.5^{\circ} \mathrm{C}, \mathrm{p}$ $=0.114)$. The changes in total alkalinity varied with temperature. The total alkalinity significantly increased in the $24^{\circ} \mathrm{C}$ group from $2420 \pm 40$ to $3360 \pm 470 \mu \mathrm{mol} \mathrm{kg}{ }^{-1}$ over the course of the experiment (linear regression, $\mathrm{p}<0.001$ ). In the $6.5^{\circ} \mathrm{C}$ group, the total alkalinity fluctuated between $2467 \pm$ 587 and $3140 \pm 68 \mu \mathrm{mol} \mathrm{kg} \mathrm{kg}^{-1}$ (linear regression, $\mathrm{p}=0.034$ ) (Figure 3b). The $\Omega_{\mathrm{ar}}$ at both temperatures followed the trends observed in total alkalinity (Figure $3 \mathrm{a}$ ). The $24^{\circ} \mathrm{C}$ group $\Omega_{\mathrm{ar}}$ increased significantly from around 1.6 to 3.4 over the course of the experiment (linear regression, $\mathrm{p}<0.001$ ) while the $6.5^{\circ} \mathrm{C}$ group fluctuated between 0.9 and 1.5 (linear regression, $\mathrm{p}=0.006)($ Figure $3 \mathrm{a})$. 


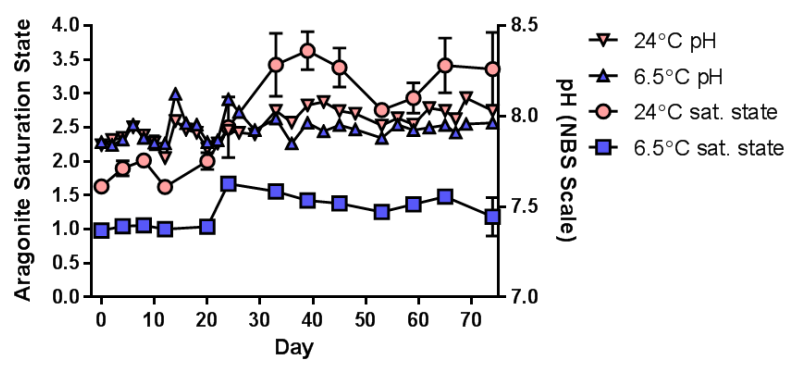

(a)

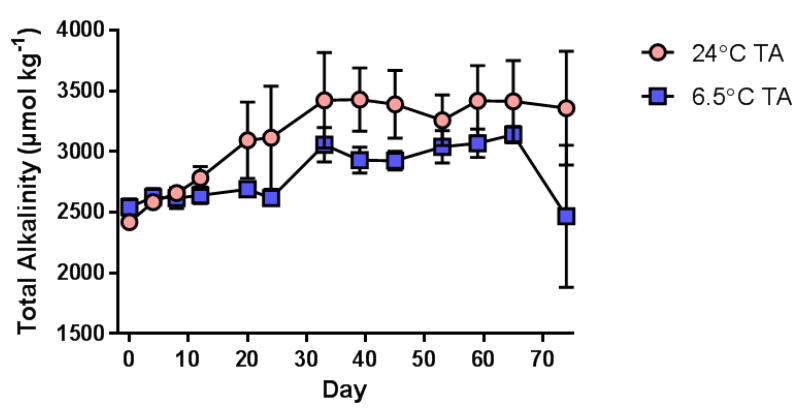

(b)

Figure 3. Overlying aquaria water $\mathrm{pH}$, aragonite saturation state, and total alkalinity. The $\mathrm{pH}$, aragonite saturation state (a), and total alkalinity (TA) (b) of the overlying water in both $6.5^{\circ} \mathrm{C}$ and $24^{\circ} \mathrm{C}$ aquaria over time. Blue points represent the $6.5^{\circ} \mathrm{C}$ aquaria $(n=3$ per point) while red points represent the $24^{\circ} \mathrm{C}$ aquaria $(n=2$ per point). Error bars are \pm standard error of the mean.

\subsection{Chemistry of Sediment with No Crushed Shell}

Significant acidification of the surface sediment from initial $\mathrm{pH}$ values $(\sim 6.9)$ down to $\mathrm{pH} \sim 6.0$ was achieved in all sediment beds that had no crushed shell applied to them (linear regression, $\mathrm{p}<0.001$ ) (Figure $4 \mathrm{a}$ ). The time that it took to reach this $\mathrm{pH}$ and time the $\mathrm{pH}$ remained around this value were temperature dependent. For the $24^{\circ} \mathrm{C}$ treatment, it took 8 days for the $\mathrm{pH}$ to drop below 6.0 , while for the $6.5^{\circ} \mathrm{C}$ treatment, it took 20 days. The $\mathrm{pH}$ for the $24^{\circ} \mathrm{C}$ treatment was $\leq 6.0 \mathrm{pH}$ for 18 days, while for the $6.5^{\circ} \mathrm{C}$ treatment, it was $\leq 6.0$ for 28 days (Figure $4 \mathrm{a}$ ). The $\mathrm{pH}$ of the sediment at 4-7 cm followed a similar trend but never went below 6.4 (Figure $4 \mathrm{~b}$ ). The $\mathrm{pH}$ values at $12-15 \mathrm{~cm}$ sediment depth remained between 6.6 and 7.0 (Figure 4c).

The total alkalinity of the surface sediment followed the same trends observed in the $\mathrm{pH}$. The total alkalinity of the $24^{\circ} \mathrm{C}$ and $6.5^{\circ} \mathrm{C}$ sediment surface groups significantly decreased from their respective initial values of $4095 \pm 145$ and $3063 \pm 554 \mu \mathrm{mol} \mathrm{kg}{ }^{-1}$ down to $410 \pm 310$ and $560 \pm 285$ $\mu \mathrm{mol} \mathrm{kg}{ }^{-1}$ by day 39 (linear regression, $\mathrm{p}=0.006$ for $24^{\circ} \mathrm{C}$ and $\mathrm{p}<0.001$ for $6.5^{\circ} \mathrm{C}$ ) before they started to increase (Figure 5a). At the 4-7 cm depth, there was an increase in the $24^{\circ} \mathrm{C}$ group total alkalinity over the course of the experiment from $3820 \pm 200$ to $9935 \pm 2695 \mu \mathrm{mol} \mathrm{\textrm {kg } ^ { - 1 }}$. The total alkalinity in the $6.5^{\circ} \mathrm{C}$ treatment, however, decreased from $3023 \pm 168$ to $2433 \pm 508 \mu \mathrm{mol} \mathrm{kg}^{-1}$ (Figure $5 \mathrm{~b}$ ). Neither of these total alkalinity changes at the 4-7 cm depth were significant (linear regression, $\mathrm{p}=0.066$ for $24^{\circ} \mathrm{C}$ and $\mathrm{p}=$ 0.352 for $6.5^{\circ} \mathrm{C}$ ). At the $12-15 \mathrm{~cm}$ depth, the average total alkalinity increased in the $24^{\circ} \mathrm{C}$ treatment over the duration of the experiment from $3885 \pm 575$ to $14505 \pm 6965 \mu \mathrm{mol}$ $\mathrm{kg}^{-1}$, but high variation between replicates prevented this increase from being statistically significant (linear regression; $\mathrm{p}=0.172$ ). The $6.5^{\circ} \mathrm{C}$ treatment total alkalinity only fluctuated between $3513 \pm 941-5907 \pm 490 \mu \mathrm{mol} \mathrm{kg} \mathrm{kg}^{-1}$ (linear regression; $\mathrm{p}=0.951$ ) (Figure 5c).

The $\Omega_{\mathrm{ar}}$ for surface sediment followed the same pattern observed for the $\mathrm{pH}$. The $\Omega_{\mathrm{ar}}$ was the lowest at the sediment surface in both temperature treatments since it dropped below 0.04 by day 20 and stayed this low until day 53 (Figure 4a). By the end of the experiment, $\Omega_{\mathrm{ar}}$ at the $24^{\circ} \mathrm{C}$ had risen back to $\sim 0.15$ while $\Omega_{\mathrm{ar}}$ at $6.5^{\circ} \mathrm{C}$ stayed below 0.04 (linear regression, $\mathrm{p}=0.840$ for $24^{\circ} \mathrm{C}$ and $\mathrm{p}=<0.001$ for $6.5^{\circ} \mathrm{C}$ ). The $4-7 \mathrm{~cm}$ and $12-15 \mathrm{~cm}$ depths in the $6.5^{\circ} \mathrm{C}$ treatment started with an $\Omega_{\mathrm{ar}} \sim 0.25$, which significantly decreased to $\sim 0.10$ by the end of the experiment (linear regression, $\mathrm{p} \leq$ $0.013)$. In the $24^{\circ} \mathrm{C}$ treatment, the $\Omega_{\mathrm{ar}}$ of the $4-7 \mathrm{~cm}$ and $12-15 \mathrm{~cm}$ depths increased over the course of the experiment until they exceeded 0.5 and 1.0 respectively (linear regression, $\mathrm{p}=0.052$ for $4-7 \mathrm{~cm}$ and $\mathrm{p}=0.096$ for $12-15 \mathrm{~cm}$ ) (Figure 4b; Figure 4c).

\subsection{Chemistry of Sediment with Crushed Shell}

When crushed shell was added on day 33 , the $\mathrm{pH}$ of the sediment surface increased from $6.24 \pm 0.01$ to $6.80 \pm 0.02$ for the $24^{\circ} \mathrm{C}$ treatment, and from $6.16 \pm 0.03$ to $6.55 \pm 0.10$ for the $6.5^{\circ} \mathrm{C}$ treatment within 6 days (Figure 6a). During this time, the total alkalinity also increased from $790 \pm 690$ to $4585 \pm 255 \mu \mathrm{mol} \mathrm{kg}{ }^{-1}$ for the $24^{\circ} \mathrm{C}$ treatment and from $443 \pm$ 99 to $3816 \pm 474 \mu \mathrm{mol} \mathrm{kg}{ }^{-1}$ for the $6.5^{\circ} \mathrm{C}$ treatment. The changes in sediment surface $\mathrm{pH}$ and total alkalinity for $24^{\circ} \mathrm{C}$ and $6.5^{\circ} \mathrm{C}$ crushed shell groups over the course of the experiment were both statistically significant (linear regression, $\mathrm{p} \leq 0.012)$. It is possible, however the $\mathrm{pH}$ and total alkalinity increases occurred in less than 3 days after the crushed shell addition since sediment chemistry was not checked sooner than this. The sediment surface $\Omega_{\mathrm{ar}}$ (starting at $\sim 0.01$ ) significantly increased after the crushed shell was applied to $0.62 \pm 0.01$ and $0.22 \pm 0.01$ for the $24^{\circ} \mathrm{C}$ and $6.5^{\circ} \mathrm{C}$ treatments, respectively, by the end of the experiment (linear regression, $\mathrm{p} \leq 0.001$ ) (Figure $7 \mathrm{a}$ ). The $\mathrm{pH}$, total alkalinity, and $\Omega_{\mathrm{ar}}$ all stayed above the values they reached after 6 days of exposure to crushed shell for the rest of the experiment. (Figure 6a; Figure 7a). A full layer of crushed shell was still visible on the sediment surface at the end of the experiment.

Some of the sediment chemistry parameters at the $4-7 \mathrm{~cm}$ depth of the crushed shell treatments also changed over the course of the experiment. The $\mathrm{pH}$ stayed between $\sim 6.4$ and $\sim 6.8$ in both temperature treatments (Figure 6b), however, the total alkalinity for the $24^{\circ} \mathrm{C}$ and $6.5^{\circ} \mathrm{C}$ treatments $(2915 \pm$ 1425 and $3720 \pm 702 \mu \mathrm{mol} \mathrm{kg}^{-1}$ ) increased to $15830 \pm 7480$ and $6397 \pm 610 \mu \mathrm{mol} \mathrm{kg} \mathrm{kg}^{-1}$, respectively, within 20 days of crushed shell application (Figure $7 \mathrm{~b}$ ). The aragonite $\Omega_{\mathrm{ar}}$ at $24^{\circ} \mathrm{C}$ increased from an initial value of $0.12 \pm 0.07$ to $0.65 \pm$ 0.05 after being exposed to crushed shell for 20 days, but the $6.5^{\circ} \mathrm{C} \Omega_{\mathrm{ar}}$ remained around 0.10 (Figure $6 \mathrm{~b}$ ). The change in 
$\mathrm{pH}$ from day 53 to 74 at $6.5^{\circ} \mathrm{C}$ was statistically significant (Repeated measures ANOVA, $\mathrm{p}=0.024$; Tukey's multiple comparison test, $\mathrm{p}=0.024)$, but all other changes were not (Repeated measures ANOVA, $\mathrm{p} \geq 0.107$ ).

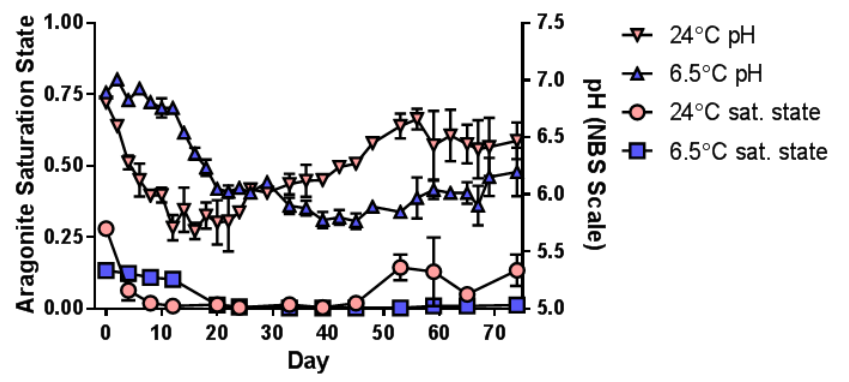

(a)

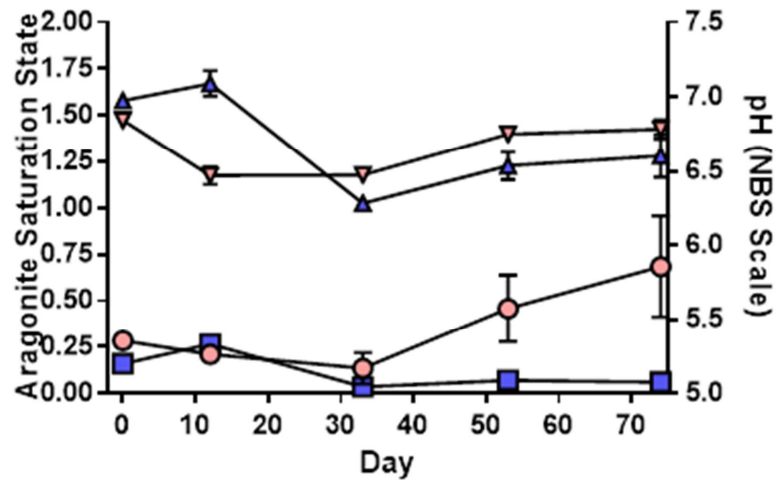

(b)

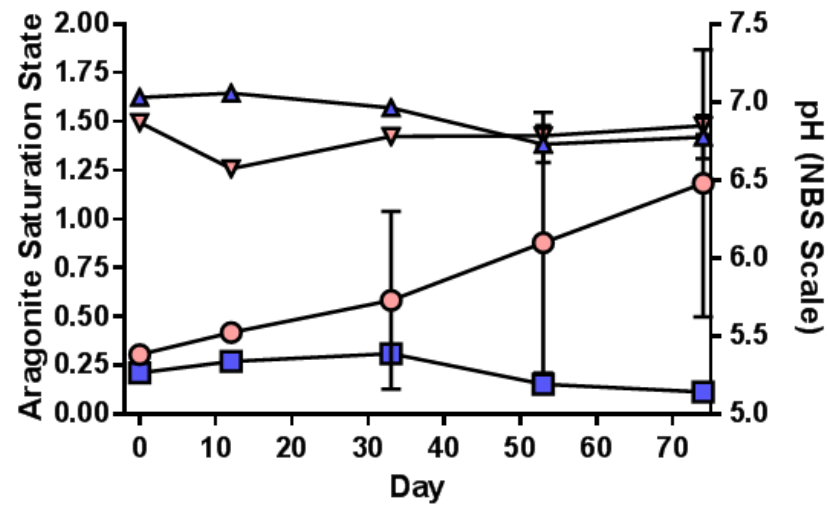

(c)

Figure 4. Sediment $\mathrm{pH}$ and aragonite saturation state of the sediment beds that had no crushed shell added. Each graph represents a different sediment depth: 0-3 cm (a) 4-7 cm (b) and 12-15 cm (c). Blue points represent the $6.5^{\circ} \mathrm{C}$ aquaria $\left(n=3\right.$ per point) while red points represent the $24^{\circ} \mathrm{C}$ aquaria $(n=2$ per point). Error bars are \pm standard error of the mean.

The sediment chemistry at the $12-15 \mathrm{~cm}$ depth of the groups treated with crushed shell were relatively stable for the duration of the experiment. The $\mathrm{pH}$ for both temperature groups was between 6.75 and 7.00 for the duration of experiment (Figure 6c). The total alkalinity for the $24^{\circ} \mathrm{C}$ treatment increased from $10975 \pm 1455 \mu \mathrm{mol} \mathrm{kg}{ }^{-1}$ on day 33 to $15780 \pm 1090 \mu \mathrm{mol} \mathrm{kg}^{-1}$ on day 53 , but the change was not significant (Repeated measures ANOVA, $\mathrm{p}=0.431$ ). The increase in the $6.5^{\circ} \mathrm{C}$ treatment from $5637 \pm 43$ to $7247 \pm 123$ $\mu \mathrm{mol} \mathrm{kg} \mathrm{kg}^{-1}$ during this period however was significant (Repeated measures ANOVA, $\mathrm{p}=0.008$; Tukey's multiple comparison test, $\mathrm{p}=0.006$ ) (Figure $7 \mathrm{c}$ ). The $\Omega_{\mathrm{ar}}$ for the $24^{\circ} \mathrm{C}$ treatment increased from $0.72 \pm 0.14$ to $1.25 \pm 0.06$ by day 53 , but this change was not statistically significant (Repeated measures ANOVA, $p=0.308$ ). No significant changes were detected in the $\Omega_{\mathrm{ar}}$ of the $6.5^{\circ} \mathrm{C}$ treatment, which remained around 0.25 (Repeated measures ANOVA, p = 0.138) (Figure $6 c)$.

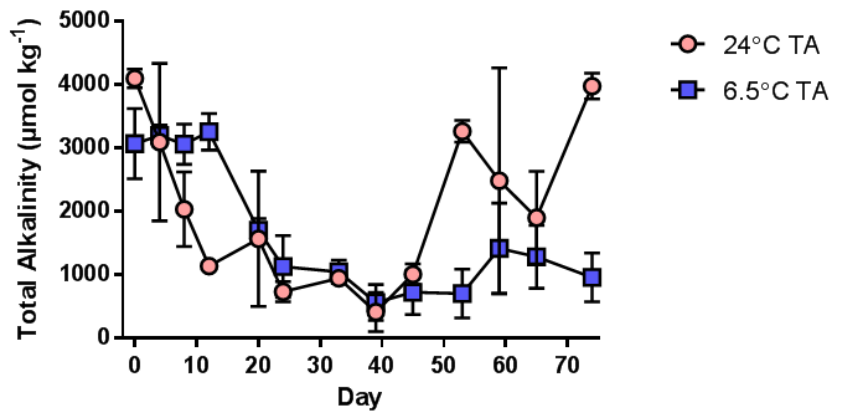

(a)

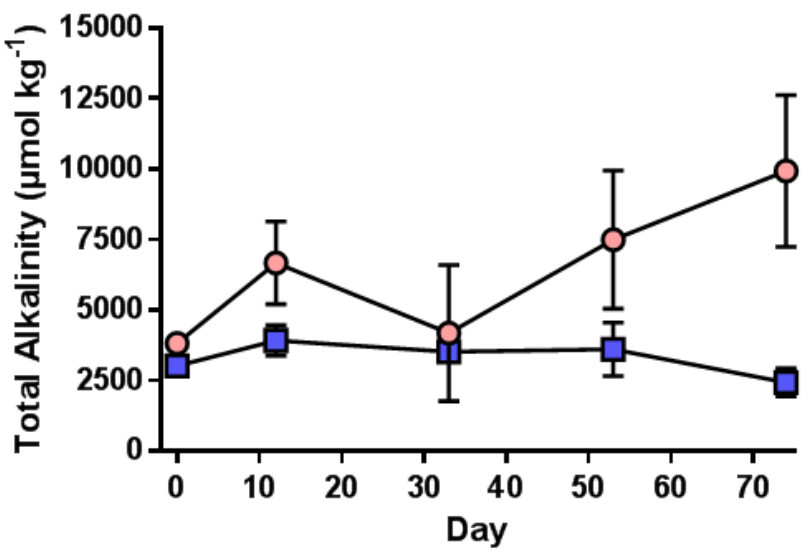

(b)

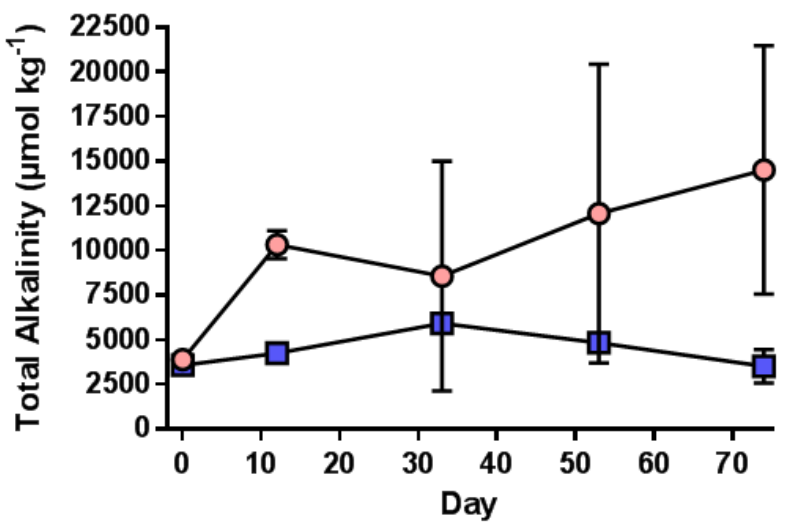

(c)

Figure 5. Sediment total alkalinity (TA) of the sediment beds that had no crushed shell added. Each graph represents a different sediment depth: 0-3 $\mathrm{cm}$ (a) $4-7 \mathrm{~cm} \mathrm{(b)} \mathrm{and} 12-15 \mathrm{~cm}$ (c). Blue points represent the $6.5^{\circ} \mathrm{C}$ aquaria $\left(n=3\right.$ per point) while red points represent the $24^{\circ} \mathrm{C}$ aquaria $(n=2$ per point). Error bars are \pm standard error of the mean. 


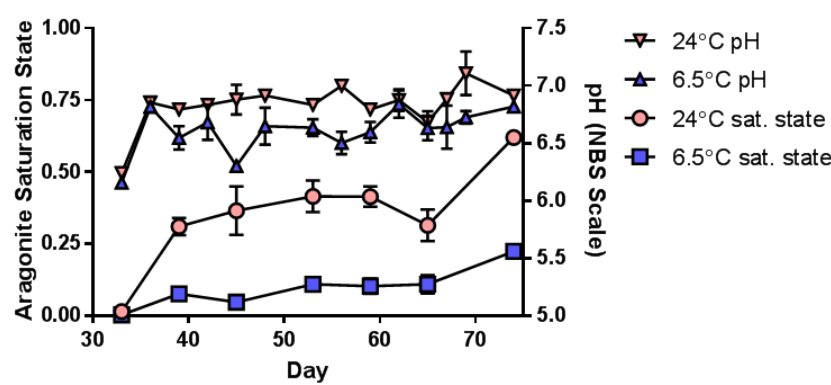

(a)

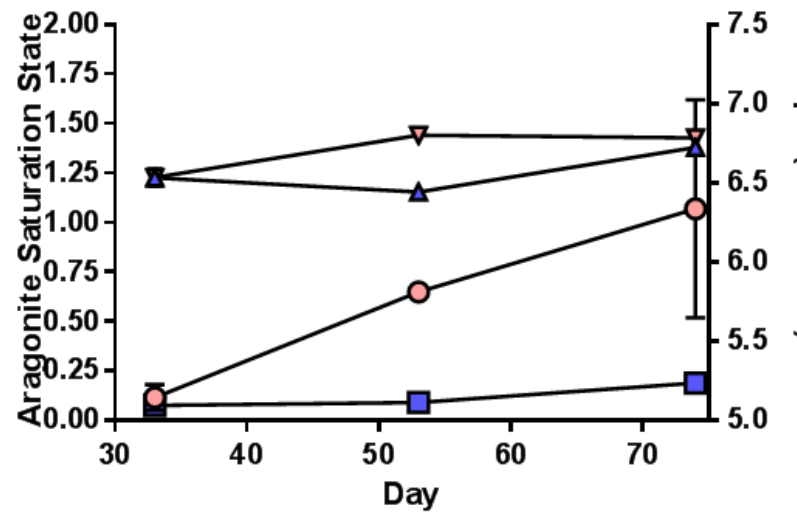

(b)

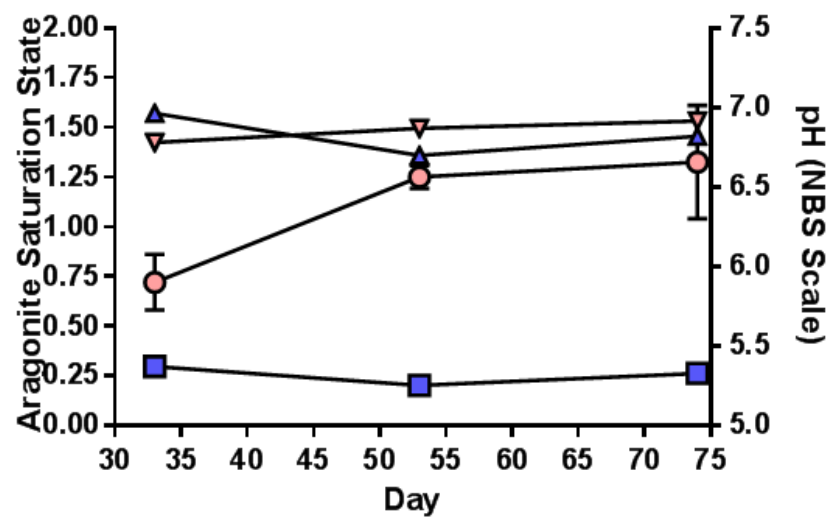

(c)

Figure 6. Sediment $p H$ and aragonite saturation state of the sediment beds that had crushed shell added to them 33 days after being placed in the 20 gallon aquaria. Each graph represents a different sediment depth: $0-3 \mathrm{~cm}$ (a) $4-7 \mathrm{~cm}$ (b) and $12-15 \mathrm{~cm}$ (c). Blue points represent the $6.5^{\circ} \mathrm{C}$ aquaria $(n=3$ per point) while red points represent the $24^{\circ} \mathrm{C}$ aquaria $(n=2$ per point). Error bars are \pm standard error of the mean.

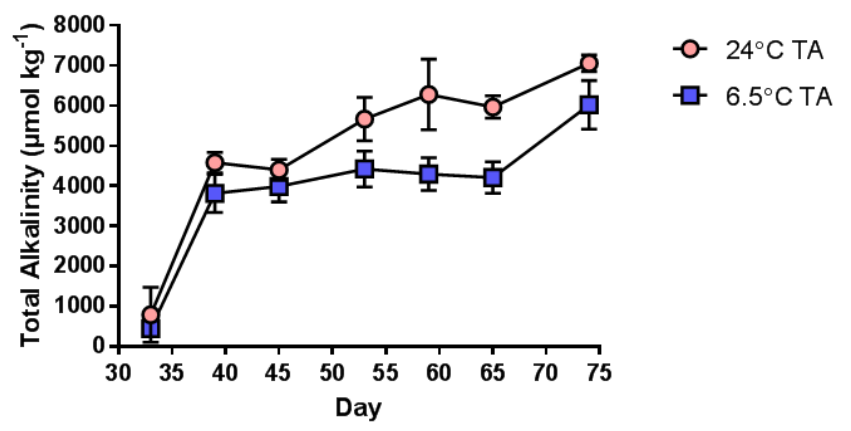

(a)

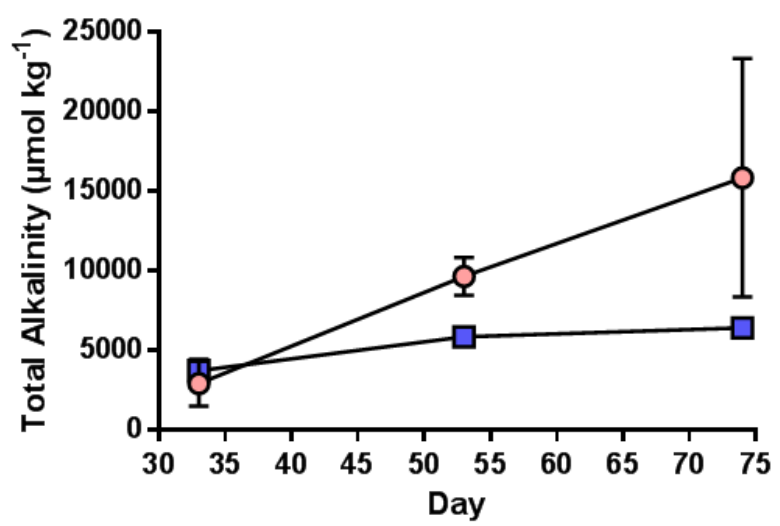

(b)

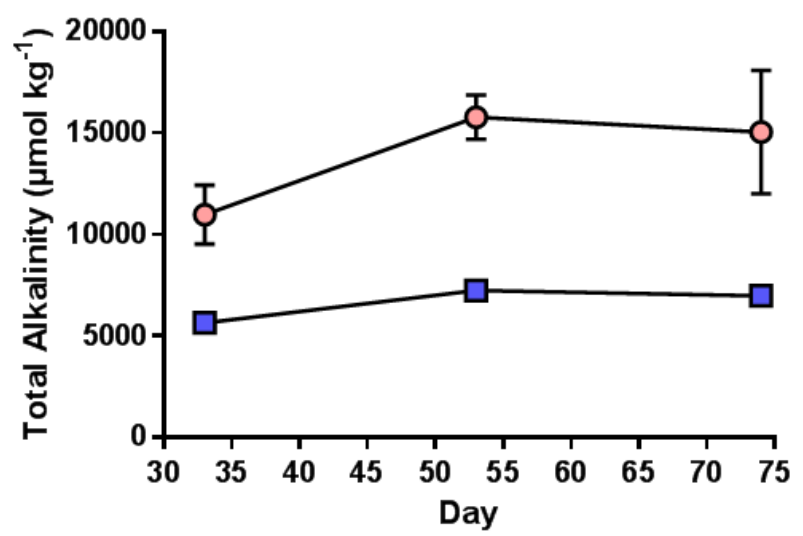

(c)

Figure 7. Sediment total alkalinity (TA) of the sediment beds that had crushed shell added to them 33 days after being placed in the 20 gallon aquaria. Each graph represents a different sediment depth: 0-3 cm (a) 4-7 $\mathrm{cm}$ (b) and $12-15 \mathrm{~cm}$ (c). Blue points represent the $6.5^{\circ} \mathrm{C}$ aquaria $(n=3 \mathrm{per}$ point) while red points represent the $24^{\circ} \mathrm{C}$ aquaria $(n=2$ point). Error bars are \pm standard error of the mean.

\section{Discussion}

The sediment acidification rate is temperature dependent because it is fueled by the metabolism of the sediment bacteria. Consequently, the incubation temperature will dictate the duration of a stable surface sediment $\mathrm{pH}$. Two different temperatures $\left(6.5^{\circ} \mathrm{C}\right.$ and $\left.24^{\circ} \mathrm{C}\right)$ were used in the current work to demonstrate the impact temperature has on acidification rate, and the stability of $\mathrm{pH}$ and total alkalinity. At both temperatures, the sediment surface $\mathrm{pH}$ stabilized at $\sim 6.0$ before starting to increase, possibly because of the limitation on the bioavailable organic matter [2]. The $24^{\circ} \mathrm{C}$ group $\mathrm{pH}$ began to increase $\sim 30$ days sooner than the $6.5^{\circ} \mathrm{C}$ group $\mathrm{pH}$ did though because bacteria consume their substrates faster at higher temperatures (Figure 4a) [29]. The surface sediment at both temperatures reached a $\mathrm{pH}$ of $6.2-6.5$ by the end of the experiment (Figure 4a). The majority of acidification occurs in the top few centimeters of the sediment in natural settings due to the availability of oxygen. This allows for the rapid production of $\mathrm{CO}_{2}$ (which decreases $\mathrm{pH}$ ) during aerobic respiration. The ammonia and phosphate produced during organic matter remineralization increase $\mathrm{pH}$ but many times 
more $\mathrm{CO}_{2}$ is produced than ammonia or phosphate on a molar basis $[2,30,31]$. The $\mathrm{pH}$ changed in the mid depths of the sediment within the course of the experiment, but only about half as much as the surface sediment (Figure $4 \mathrm{~b}$ ). The sediments at the bottom of the beds and the overlying water however both had a stable $\mathrm{pH}$ for the duration of the experiment (Figure 3a; Figure 4c). This may be because some of the $\mathrm{CO}_{2}$ produced from the various types of anaerobic respiration at lower depths of the sediment column were used to fuel methanogenesis, the type of anaerobic respiration used when $\mathrm{CO}_{2}$ is the only electron acceptor available [2].

The total alkalinity levels of the overlying water and surface sediment followed the $\mathrm{pH}$ trends. The total alkalinity levels of the 4-7 and $12-15 \mathrm{~cm}$ sediment depths in the $24^{\circ} \mathrm{C}$ treatment; however, did not follow $\mathrm{pH}$ trends. Instead, they increased over time to values that were at least twice as much as the collection site averages (Figure 5b, Figure 5c, Figure 7b, Figure 7c). Total alkalinity increased with depth in the sediment beds regardless of whether shell was added to the surface (Figure 5.; Figure 7). The total alkalinity of the $24^{\circ} \mathrm{C}$ overlying water also increased over time but not in the $6.5^{\circ} \mathrm{C}$ overlying water (Figure 3b). This suggests that the total alkalinity increase may have been caused by sulfate reduction occurring at depth in the sediment [32]. Sulfate reduction produces alkalinity, but the added alkalinity can be removed by regular water exchange between the sediment and water column [32]. The absence of water changes in the current study likely allowed alkalinity to build up in the sediments and thus act as an alkalinity source to the overlying waters. Microbial metabolism speed increases with temperature, which is likely why the large total alkalinity increases were only seen in the $24^{\circ} \mathrm{C}$ group [33]. Changing the overlying water regularly however should prevent total alkalinity increases from occurring in the overlying water and sediment depths.

The $\mathrm{pH}$, total alkalinity, and $\Omega_{\mathrm{ar}}$ of the $24^{\circ} \mathrm{C}$ and $6.5^{\circ} \mathrm{C}$ acidified surface sediments all increased from the time of crushed shell application such that the $\Omega_{\mathrm{ar}}$ reached values equal or greater to those found at the collection site surface sediment $(0.22 \pm 0.05)$ by the end of the experiment (Figure 6a; Figure 7a). The crushed shell might also be applied to the sediment before it acidifies as a preventive measure as other researchers have done [6, 19]. A treatment with a similarly sized material not made of calcium carbonate (such as gravel) was not used in the current study so it is difficult to pinpoint how much of the change in chemistry is due to possible mixing of overlying water with sediment pore waters and how much of it was due to the calcium carbonate dissolving. Either way, the crushed shell seems to be an effective of way of counteracting natural surface sediment acidification in the lab. A single treatment of 150 grams crushed shell per sediment bed (spread evenly across the sediment surface to obtain $1.4 \mathrm{~g}$ $\mathrm{cm}^{-2}$ ) kept sediment $\mathrm{pH}$ at $\sim 7.0$ for at least a month (Figure $6 \mathrm{a}$ ). All the treated sediment beds still had a full layer of crushed shell at the end of the experiment, which indicates there was likely still enough crushed shell remaining to buffer the surface sediments beyond a month. Researchers may be able to obtain the same effect with less crushed shell than 150 grams if they crush the shell down to a size of $1 \mathrm{~mm}$ instead of the $\sim 2.50 \mathrm{~mm}$ size that used in the current study since smaller shell pieces dissolve faster [19].

The method described here can be used to acidify surface sediments for experiments with benthic organisms lasting about around 30 days if a sediment surface $\mathrm{pH}$ of around 6.0 is desired. The possibility exists for experiments to be carried out with sediment surface $\mathrm{pH}$ values around 6.5 after 55 days of incubation at $24^{\circ} \mathrm{C}$, but the stability of this $\mathrm{pH}$ past 13 days is unknown. This allows researchers to investigate the effects of short-term or medium-term sediment acidification impacts on benthic organisms. The organisms to be used in an experiment should not be added to the sediment until after the initial sediment incubation period of 10 to 20 days (depending on researcher's choice of temperature) in the aquaria to insure the chemistry has stabilized within the desired range. Crushed shell should be added to the sediment beds intended to be used as controls at the start of the sediment incubation period to keep chemistry similar to that of the collection site. Regardless of the desired $\mathrm{pH}$ or temperature, it should not be assumed that this method works the same for all types of sediments because the sediment $\mathrm{pH}$ can change with organic matter content and grain size [4]. Even if the sediment to be used is of similar composition to that in the current work, researchers should run a preliminary experiment with the sediment they intend to use in their experiments to insure acidification intensity and duration are sufficient at the planned experiment's temperature. Application of crushed shell as a way to counteract acidification in control groups should be included in the preliminary experiment. The duration and temperature of the sediment incubation as well as the crushed shell amounts can all be modified to meet the researcher's needs.

The natural acidification method may not be suitable for all acidification experiments since it has some limitations. Temperature affects a variety of biological and physiological processes (such as behavioral responses of clams to acidification), which can cause confounding effects when trying to measure the impacts of both acidification and temperature together [34]. A control and acidified group with replicate aquaria should be run at each temperature so the effects of temperature alone can be isolated. The sediment $\mathrm{pH}$ can only be constrained to values of $\sim 6.0$ or $\sim 6.5$ rather than the wide range of values that can be obtained by bubbling $\mathrm{CO}_{2}$. The sediment must also be collected at least 10 days before the animals are placed in the sediment to allow for acidification to take place. Variation of the sediment bacteria populations between different samples of sediment may also affect the acidification rates. Multiple sediment beds should be used within each group of the experiment to help account for this. If any other environmental parameters or pollutants are being experimented with in addition to sediment chemistry, the researchers must insure during a preliminary trial to determine if the additional variable (s) impact the acidification rate of the sediment.

There are other methods to acidify sediments although they each have their own set of limitations as well [16]. The 
method used most often is to bubble $\mathrm{CO}_{2}$ gas directly into the sediment. This allows for precise control of the sediment $\mathrm{pH}$ for any duration but does not mimic natural acidification. Gelatin can be placed under the acidified sediment to keep the $\mathrm{pH}$ stable of both lab and field sediments, but the stability only holds for 24-48 hours [7]. Another method is to find sediments already at the desired $\mathrm{pH}$ in the field and collect them using a core sampler. This method mimics the natural environment but can only be used for short-term experiments since the native sediment bacteria will begin to change the sediment chemistry [7].

\section{Conclusions}

The current work shows natural acidification can be manipulated with temperature and counteracted with crushed E. leei shell in the laboratory. The method described here can be used to naturally acidify the surface of sediments comprised of at least $75 \%$ fine to very fine sand kept within recirculating aquaria down to $\mathrm{pH} \sim 6.0$ and an $\Omega_{\mathrm{ar}} \sim 0$ for 20 to 50 days, depending on temperature (Figure $4 \mathrm{a}$ ). This $\mathrm{pH}$ corresponds to some of the more acidic values recorded in surface sediments [4]. Adding the crushed E. leei shells to the sediment surface increased the $\mathrm{pH}$ to values similar to those at the collection site $(\sim 6.8)$ within three days of application (Figure 6a). The crushed shells can thus be used to maintain a control group with a $\mathrm{pH}$ close to that of the field sediment. Crushed $E$. leei shell also has the potential to buffer field sediments although field trials will be needed to confirm this. Additional studies will be needed to test if the natural acidification method works with other sediment types as well as flow-through systems. There is no single method that can be used for all possible sediment acidification experiments, however the current study should help expand the tool kit for researchers studying the effect of sediment acidification on marine benthic organisms such as bacteria, worms, bivalves, crabs, and lobsters.

\section{Acknowledgements}

This project was supported by the USDA National Institute of Food and Agriculture, Hatch (or McIntire-Stennis, Animal Health, etc.) Project number ME0-21803 through the Maine Agricultural \& Forest Experiment Station. Maine Agricultural and Forest Experiment Publication Number 3717. This work was also supported by the National Science Foundation under Grant \#IIA-1355457 to Maine EPSCoR at the University of Maine. The authors would like to thank the staff in the Department of Civil and Environmental Engineering for use of their drying oven, furnace, and sieves.

\section{References}

[1] Green M. A., Gulnick J. D., Dowse N., et al. (2004). Spatiotemporal patterns of carbon remineralization and bio-irrigation in sediments of Casco Bay Estuary, Gulf of Maine. Limnology and Oceanography 49, 396-407.
[2] Widdicombe S., Spicer J. I., Kitidis V. (2011). Effects of ocean acidification on sediment fauna. Ocean Acidification 16.

[3] Pimenta A., Grear J. (2018). Guidelines for Measuring Changes in Seawater pH and Associated Carbonate Chemistry in Coastal Environments of the Eastern United States. US Office of Research and Development Washington, DC, EPA/600/R-17/483.

[4] Clements J. C., Hunt H. L. (2018). Testing for Sediment Acidification Effects on Within-Season Variability in Juvenile Soft-Shell Clam (Mya arenaria) Abundance on the Northern Shore of the Bay of Fundy. Estuaries and Coasts 41, 471-483.

[5] Friends of Casco Bay. 2013 Casco Bay clam flat pH study [Internet]. $2014 . \quad$ Available from: https://www.cascobayestuary.org/wp-content/uploads/2018/01 /Casco-Bay-Clamflat-pH-Study-FOCB-2013.pdf.

[6] Green M. A., Waldbusser GG, Reilly SL, et al. (2009). Death by dissolution: sediment saturation state as a mortality factor for juvenile bivalves. Limnology and Oceanography 54, 1037 1047.

[7] Clements J. C., Woodard K. D., Hunt HL. (2016). Porewater acidification alters the burrowing behavior and post-settlement dispersal of juvenile soft-shell clams (Mya arenaria). Journal of Experimental Marine Biology and Ecology. 477, 103-111.

[8] Waldbusser G. G., Hales B., Haley B. A. (2016). Calcium carbonate saturation state: on myths and this or that stories. ICES Journal of Marine Sciences 73, 563-568.

[9] Cohen A. L., Holcomb M. (2009). Why Corals Care About Ocean Acidification: Uncovering the Mechanism. Oceanography 22, 118-127.

[10] Palmer A. R. (1992). Calcification in marine molluscs: how costly is it? PNAS 89, 1379-1382.

[11] Pan T-C. F., Applebaum S. L., Manahan D. T. (2015). Experimental ocean acidification alters the allocation of metabolic energy. PNAS 112, 4696-4701.

[12] Clements J. C., Hunt H. L. (2014). Influence of sediment acidification and water flow on sediment acceptance and dispersal of juvenile soft-shell clams (Mya arenaria L.). Journal of Experimental Marine Biology and Ecology 453, 62-69.

[13] Waldbusser G., Bergschneider H., Green M. (2010). Size-dependent $\mathrm{pH}$ effect on calcification in post-larval hard clam Mercenaria spp. Marine Ecology Progress Series 417, 171-182.

[14] Rodríguez-Romero A., Jiménez-Tenorio N, Basallote M. D., et al. (2014). Predicting the Impacts of $\mathrm{CO}_{2}$ Leakage from Subseabed Storage: Effects of Metal Accumulation and Toxicity on the Model Benthic Organism Ruditapes philippinarum. Environmental Science \& Technology 48, 12292-12301.

[15] Leavitt D. Biology of the Atlantic Jackknife (Razor) Clam (Ensis directus Conrad, 1843) [Internet]. Northeastern Regional Aquaculture Center; 2010. Available from: https://agresearch.umd.edu/sites/agresearch.umd.edu/files/_im ages/uploaded/NRAC\%20217-2010.pdf.

[16] Clements J. C., Hunt H. L. (2017). Effects of $\mathrm{CO}_{2}$-driven sediment acidification on infaunal marine bivalves: A synthesis. Marine Pollution Bulletin 117, 6-16. 
[17] Dickson A. G., Sabine C. L., Christian J. R. Guide to Best Practices for Ocean $\mathrm{CO}_{2}$ Measurements. [Internet]. North Pacific Marine Science Organization; 2007 [cited 2018 Sep 18] Available from: https://www.oceanbestpractices.net/handle/11329/249.

[18] Riebesell U., Fabry V. J., Hansson L., et al. Guide to best practices for ocean acidification research and data reporting [Internet]. Riebesell U, Fabry VJ, Hansson L, et al., editors. Luxembourg: Office for Official Publications of the European Communities; 2011 [cited 2018 Sep 18]. Available from: https://oceanrep.geomar.de/8471/.

[19] Green M. A., Waldbusser G. G., Hubazc L., et al. (2013). Carbonate Mineral Saturation State as the Recruitment Cue for Settling Bivalves in Marine Muds. Estuaries and Coasts 36, 18 27.

[20] Greiner C. M., Klinger T., Ruesink J. L., et al. (2018). Habitat effects of macrophytes and shell on carbonate chemistry and juvenile clam recruitment, survival, and growth. Journal of Experimental Marine Biology and Ecology 509, 8-15.

[21] Cubillas P, Köhler S, Prieto M, et al. (2005). Experimental determination of the dissolution rates of calcite, aragonite, and bivalves. Chemical Geology 216, 59-77.

[22] Areibat L. E. M., Kamari A. (2017). Razor clam (Ensis directus) shell as a low-cost adsorbent for the removal of Congo red and Rhodamine B dyes from aqueous solution. AIP Conference Proceedings 1847.

[23] Drupp P. S., De Carlo E. H., Mackenzie F. T. (2016). Porewater $\mathrm{CO}_{2}$-carbonic acid system chemistry in permeable carbonate reef sands. Marine Chemistry 185, 48-64.

[24] Ries J. B. (2011). Skeletal mineralogy in a high- $\mathrm{CO}_{2}$ world. Journal of Experimental Marine Biology and Ecology 403, 5464

[25] López G. I. Grain Size Analysis. In: Gilbert AS, editor. Encyclopedia of Geoarchaeology [Internet]. Dordrecht:
Springer Netherlands; 2017 [cited 2018 Dec 28]. p. 341-348. Available from: https://doi.org/10.1007/978-1-4020-4409-0_18.

[26] Wentworth C. K. (1922). A Scale of Grade and Class Terms for Clastic Sediments. The Journal of Geology 30, 377-392.

[27] Heiri O., Lotter A. F., Lemcke G. (2001). Loss on ignition as a method for estimating organic and carbonate content in sediments: reproducibility and comparability of results. Journal of Paleolimnolpgy 25.

[28] Millero F. J. (2010). Carbonate constants for estuarine waters. Marine and Freshwater Research 61, 139-142.

[29] Pomeroy L., Wiebe W. (2001). Temperature and substrates as interactive limiting factors for marine heterotrophic bacteria. Aquatic Microbial Ecology 23, 187-204.

[30] Soetaert K., Hofmann A. F., Middelburg J. J., et al. (2007). The effect of biogeochemical processes on $\mathrm{pH}$. Marine Chemistry, 105: $30-51$

[31] Widdicombe S., Dashfield S. L., McNeill C. L., et al. (2009). Effects of $\mathrm{CO}_{2}$ induced seawater acidification on infaunal diversity and sediment nutrient fluxes. Marine Ecology Progress Series 379, 59-75.

[32] Whitworth K. L., Silvester E., Baldwin D. S. (2014). Alkalinity capture during microbial sulfate reduction and implications for the acidification of inland aquatic ecosystems. Geochimica et Cosmochimica Acta 130, 113-125.

[33] Arnosti C., Jørgensen B., Sagemann J., et al. (1998). Temperature dependence of microbial degradation of organic matter in marine sediments: polysaccharide hydrolysis, oxygen consumption, and sulfate reduction. Marine Ecology Progress Series $165,59-70$.

[34] Clements J. C., Bishop M. M., Hunt H. L. (2017). Elevated temperature has adverse effects on GABA-mediated avoidance behaviour to sediment acidification in a wide-ranging marine bivalve. Marine Biology 164. 